\title{
Forced sexual relations among married young women in developing countries
}

\author{
Deepika Ganju \\ Population Council \\ William Finger \\ Shireen J. Jejeebhoy \\ Population Council \\ Vijaya Nidadavolu \\ K.G. Santhya \\ Population Council
}

See next page for additional authors

Follow this and additional works at: https://knowledgecommons.popcouncil.org/departments_sbsr-pgy

Part of the Family, Life Course, and Society Commons, Gender and Sexuality Commons, and the International Public Health Commons

How does access to this work benefit you? Let us know!

\section{Recommended Citation}

Ganju, Deepika, William Finger, Shireen J. Jejeebhoy, Vijaya Nidadavolu, K.G. Santhya, Iqbal Shah, Shyam Thapa, and Ina Warriner. 2004. "Forced sexual relations among married young women in developing countries," research brief. New Delhi: Population Council. 


\section{Authors}

Deepika Ganju, William Finger, Shireen J. Jejeebhoy, Vijaya Nidadavolu, K.G. Santhya, Iqbal Shah, Shyam Thapa, and Ina Warriner 


\section{Forced sexual relations among married young women in developing countries}

perpetrate such incidents. In Uttar Pradesh, India for example, one-third of men aged 30 or less and onefourth of older men reported ever perpetrating nonconsensual sex (with or without physical force) on their wives. Another study in Uttar Pradesh similarly reports that young men (those married less than 10 years) are significantly more likely to have recently perpetrated sexual violence on their wives than those married longer. Men also reported perpetrating current episodes of sexual violence on their wives. In three states in India (Punjab, Rajasthan and Tamil Nadu), about two-third of men aged 15-24 and 43 per cent of men aged 36-50 had perpetrated violence on their wives in the 12 months preceding the investigation. ${ }^{6}$

\section{Forced sex is initiated early and is not an isolated incident}

Several presentations made at the New Delhi meeting reiterated that there is little variation in the lifetime experience of non-consensual marital sex reported by young women (aged 15-24) and older women (aged 30-39). ${ }^{7}$ Given the significantly shorter exposure period of young women, this finding underscores the fact that forced sex is initiated early in the marriages of young women. National-level data in Latin America and the Caribbean, where partner choice is more prevalent than in South Asia, for example, suggest that coercion is initiated early, often within the first two years of marriage. In Nicaragua, half of partner violence among adolescent married women (15-19 years) started within two years of marriage. ${ }^{8}$

In studies in South Asia, a region known for early and arranged marriages in which decision-

making tends to exclude the young woman, early marital experiences and notably sexual initiation are also reported to be forced for many.

Qualitative studies from Bangladesh, various parts of India and Nepal highlight the vulnerability of newly married adolescent girls who undergo arranged marriage, and are neither familiar with their husbands nor informed about sexual matters. In-depth interviews with women married in adolescence reiterate the point that early marital relations were coerced, traumatic and painful. Testimonies from young women in South Asia reflect their fear and helplessness during such incidents. In one study in Gujarat, India, a woman said: "my husband insisted on doing it every day...I would cry and tell him it was painful...still he would continue". In another study in Uttar Pradesh, women reported similar experiences of their wedding night. For example, one woman said: "It was a terrifying experience; when I tried to resist he pinned my arms above my head". Another, married at 13 years, says: "Nobody would call this a normal sexual encounter. It can only correctly be labelled as 'rape' by her own man”. A third asks: "How can a child of twelve and a half enjoy that?" In Mumbai, a woman recalled: "When he did it for the first time, it was painful. I cried for days".

Sexual coercion is not limited to single isolated episodes. Studies in at least two settings (Haiti and Nicaragua) report that most young women who had experienced sexual coercion in the preceding 12 months had suffered three or more incidents during the period. ${ }^{10}$

\section{Gender power imbalances and sexual violence}

\section{Young women's lack of autonomy}

While unequal power relations and lack of autonomy characterize the situation of married women in many settings, the autonomy of married young women is particularly constrained. In many countries in South Asia and the Middle East, early and arranged marriages are the norm and in most cases, the young woman scarcely knows her husband and is not involved in marriage-related decision-making. A young woman's powerlessness and inability to exercise sexual choices in her marital home exacerbate the non-consensual nature of early sex, particularly forced sexual initiation. Lack of information on sexual matters at marriage compounds the anxiety and fear that characterizes young women's early marital experiences, particularly as young husbands are better informed and in many cases, sexually experienced before marriage. In contrast, studies in several settings imply that marriage in adulthood enables women to enter marriage on more equal terms than marriage in adolescence. For example, studies in India reveal that women who married in adulthood were more likely to report that marital sexual experiences were "positive" compared to those married in adolescence. In Bangladesh, women married at 20 or later were more likely to have negotiated first sex than those who married in adolescence. ${ }^{11}$ 
Even in other settings not as prominently characterized by early and arranged marriage, women who married young were more vulnerable to early coercive sex. Findings from Latin America suggest that married young women had little autonomy and choice, and were at far greater risk of both physical and sexual violence from their partners compared to women who married later. Younger women were also more likely to have suffered current and more severe episodes of violence, experienced violence in pregnancy and suffered injuries and other negative health outcomes. ${ }^{12}$ Qualitative studies reinforce this finding. For example, in Rio de Janeiro, Brazil, a woman married in adolescence said: "I screamed. He said, 'You have to do it.' It was a sad bloodbath, the next day I couldn't even walk." ${ }^{13}$

\section{Male entitlement to force sex}

In many developing countries women "believe" that the use of force is a man's "right" and submission is the only way to avoid pain and ensure security in the marital home. Young women from various settings in South Asia said or were told: "I had feelings of discomfort but I had to accept my husband's wishes." "If you won't give him then he will force you and you would have pain". ${ }^{14}$ In Zimbabwe women were told that the use of force by a husband is "a part of life". ${ }^{15}$ In Nicaragua and Haiti, it was believed that women did not have the right to refuse sex if they did not feel like it, and that in some circumstances men were justified in beating their wives. ${ }^{16}$

Gender norms stress male entitlement to sex, even if forced within marriage. In Nepal, 11 per cent of younger men (below age 30) and 8 per cent of men aged 30-39 years justified wife-beating for refusing sex. ${ }^{17}$ Men use threats of abandonment, seeking sexual gratification elsewhere, remarriage and quarrel to force sex upon wives early in marriage. Few husbands respect their wives attempts to refuse their sexual advances. A young woman from Bangladesh said: "My husband used to get angry... and told me that he would remarry if I refused to have sex with him." ${ }^{18}$

\section{Emerging evidence of changing attitudes, greater autonomy}

While prevailing norms in many developing societies support male dominance in marital partnerships, there is evidence to suggest that women's perceptions and attitudes to their partners may be changing. In Latin America, while men feel a sense of entitlement to force sex, and young women feel a sense of powerlessness to negotiate sexual relations, cultural norms may be changing making it more acceptable for younger women to leave violent relationships. In Nicaragua, for instance, while older women continue to stay longer in violent relationships, younger women (15-24 years) are developing a greater sense of autonomy and are more likely to seek help early. ${ }^{19}$

In South Asia, where marriages are early and arranged, young women and men are recognizing the need for autonomy. In Nepal, both females and males overwhelmingly support women's right to refuse sex..$^{20}$ Large proportions of male and female college students in India argue that women must make reproductive decisions and that a man cannot force his wife to engage in unwanted sexual relations. In some settings, younger women are playing a more active role in choosing their husbands and making marriage-related decisions, which may allow women to exercise sexual choice and rights. ${ }^{21}$

Evidence suggests that as marital partnerships become more established, even in settings characterized by limited autonomy, women do indeed develop strategies to counter sexual violence. Evidence from South Asia suggests for example that sexual experiences later in marriage are varied. For many, passive acceptance tends to replace the trauma that accompanies early coerced sexual relations with their husbands due to the lack of options or as a strategy for survival. Other women have, however, developed strategies to avoid unwanted sex: they threaten to scream, endangering the husband's prestige, they threaten suicide, they wake young children or feign menstruation. In some cases, women have forged greater intimacy in their relationships with the husband and this has resulted in more sexually equitable and pleasurable relationships and the ability to communicate on sexual matters.

\section{Summing up}

While there is heterogeneity between different cultural contexts, several similarities characterize the early marital sexual experiences of young women.

- In every setting in which data are available, a considerable number of married young women experience coercive sex within marriage.

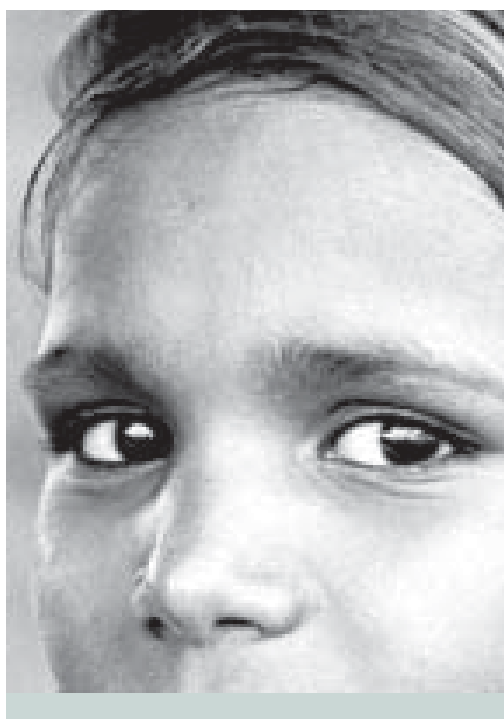

Global consultative meeting on nonconsensual sex among young people

In September 2003, a global consultative meeting on nonconsensual sex among young people in developing countries was held in New Delhi, India. The meeting was organized by Population Council in collaboration with World Health Organization/Department of Reproductive Health and Research, and Family Health International/YouthNet. Participants included researchers, legal analysts, representatives from community-based NGOs, policy makers, and young people themselves.

Sessions examined the following issues in relation to non-consensual sex: experiences of young females and males: prevalence, forms and contexts; youth perspectives, through a panel of seven youth; patterns of transactional sex; roles of the legal system; outcomes of coercion at the individual and community level; interventions to prevent non-consensual sex, and to support and treat victims; and research design and methods. 
- In most settings sexual coercion is initiated early in marriage, and in settings characterized by early and arranged marriage, specifically at sexual initiation.

- Women who marry in adolescence are more likely than others to experience more episodes of violence compared to women who marry later.

- Irrespective of setting, gender power imbalances tend to underlie the persistence of forced marital sex among young women. Powerlessness and the inability to negotiate wanted outcomes characterize married young women's narratives in Latin America just as they characterize the narratives of married young women in South Asia who exercise far less choice in early and arranged marriages, and who may be particularly unable to negotiate wanted early or first sex.

- While in most settings, gender norms emphasize women's submissiveness and male entitlement to force sex, there is emerging evidence of changing attitudes and greater autonomy among young women. For example, some young women in Latin America are leaving abusive relationships; and in South Asia some young women express awareness of their sexual rights and choices, and display attitudes opposing forced marital sex. As marital partnerships mature, moreover, several women who experienced sexual violence in early marital relations in South Asia report strategies that enable them to resist forced sexual relations or forge more equitable partnerships.

\section{Recommendations for action}

Papers and deliberations at the New Delhi meeting suggested several recommendations for action to address factors that heighten young women's vulnerability to coercive sexual relationships within marriage.

- Prepare young women who are about to be married by providing them with information on sexual matters, and ensuring that they have the ability to communicate on sexual matters with the family and future partners, and the skills to negotiate wanted sexual outcomes.

- Provide young women and men who are about to be married sexuality and life skills education to address gender stereotypes and attitudes that reinforce male entitlement and women's submissiveness to forced sex within marriage.

- Sensitize parents to the need to provide their daughters with a supportive environment.

- Advocate delayed marriage among adult gatekeepers and enable young brides-to-be to play a more active role in decisions concerning their marriage.

- Provide married women who suffer forced sexual relations access to legal structures that are sensitive to their needs and vulnerabilities.

- Given the paucity of data on the subject, research is needed on the prevalence, forms and context of sexual coercion among married young women in different settings.

- Involve men in positive ways to change gender norms that lead to violence and to establish partnerships that are based on mutual understanding and a respect for each other's rights.

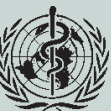

World Health Organization

\section{YsuthNet}

For further information please contact: Population Council

Zone 5A, India Habitat Centre Lodi Road, New Delhi - 110003

Ph.: +91 11 24642901/2

Fax: +911124642903 email: info@pcindia.org

www.popcouncil.org

Deepika Ganju, in collaboration with Shireen Jejeebhoy, Vijaya Nidadavolu and K.G. Santhya (Population Council); William Finger and Shyam Thapa (Family Health International/ YouthNet); and lqbal Shah and Ina Warriner (World Health Organization/ Reproductive Health and Research).

\section{References}

References to presentations from Non-consensual Sexual Experiences of Young People in Developing Countries: A Consultative Meeting, New Delhi, India, September 22-25, 2003 are noted as New Delhi meeting.

1 Im-em, W. et al. 2003. Sexual coercion among women in Thailand: Results from the WHO multicountry study on women's health and life experiences, New Delhi meeting.

2 Heise, L., K. Moore and N. Toubia. 1995. Sexual Coercion and Reproductive Health: A Focus on Research. New York: Population Council.

3 Jejeebhoy, S. and K.G. Santhya. 2003. Forced sex within marriage among young women: Evidence from South Asia, New Delhi meeting.

4 Ellsberg, M. 2003. Coerced sex among adolescents in Latin America and the Caribbean, New Delhi meeting.

5 Garcia-Moreno, C. 2003. Relationship violence experiences of young people: Findings from the WHO VAW study, New Delhi meeting.

6 Duvvery, N. et al. 2002. Links between masculinity and violence: Aggregate analysis. In Domestic Violence in India: Exploring Strategies, Promoting Dialogue. Men, Masculinities and Domestic Violence in India-Summary Report of Four Studies. Washington D.C., ICRW; Koenig, M.K. et al. 2004. Individual and contextual determinants of domestic violence in north India. Unpublished paper.

7 Ellsberg, New Delhi meeting; Jejeebhoy and Santhya, New Delhi meeting.

8 Ellsberg, New Delhi meeting.

9 Joshi, A. et al. 2001. Experiences and perceptions of marital sexual relationships among rural women in Gujarat, India. Asia-Pacific Population Journal 16(2): 177-94; Khan, M.E. et al. 1996. Sexual violence within marriage. Seminar 447: 32-35; George, A. and S. Jaswal. 1995. Understanding Sexuality: Ethnographic Study of Poor Women in Bombay. Women and AIDS Program Research Report Series no. 12, Washington D.C.: ICRW.

10 Ellsberg, New Delhi meeting.

11 Joshi, et al., op. cit.; Khan, M.E. et al. 2002. Behind closed doors: A qualitative study on sexual behaviour of married women in Bangladesh. Culture, Health and Sexuality 4(2): 133-51; Ouattara, M. et al. 1998. Forced marriage, forced sex: The perils of childhood for girls. Gender and Development 6(3): 27-33.

12 Ellsberg, New Delhi meeting.

13 Goldstein, D.M. 1994. AIDS and women in Brazil:
The emerging problem. Social Science and Medicine 39(7): 919-929.

14 George, A. 2003. Newly married adolescent women: Experiences from case studies in urban India. In S. Bott et al., eds, Towards Adulthood: Exploring the Sexual and Reproductive Health of Adolescents in South Asia, pp. 67-72, Geneva: WHO; Santhya, K.G. et al. 2001. First time parents project, supplemental diagnostic report, Kolkata, unpublished.

15 Hof, C. and A. Richters. 1999. Exploring intersections between teenage pregnancy and gender violence: Lessons from Zimbabwe. African Journal of Reproductive Health 3(1): 51-65.

16 Ellsberg, New Delhi meeting.

17 Jejeebhoy and Santhya, New Delhi meeting.

18 Khan et al., 2002, op. cit.

19 Ellsberg, New Delhi meeting.

20 Jejeebhoy and Santhya, New Delhi meeting.

21 Society for Operations Research and Training (SORT). 1998. Interest and awareness of University students on family life and reproduction: A study in MS University, Vadodara. Vadodara, SORT monograph. 